Available online at : http://journal.unj.ac.id/unj/index.php/gjik

Gladi : Jurnal Ilmu Keolahragaan 09 (02) 2018, 108 - 118

Permalink/DOI: https://doi.org/10.21009/GJIK.092.04

\title{
PENGARUH METODE LATIHAN DAN POWER TERHADAP KEMAMPUAN JUMP SERVICE BOLA VOLI
}

\author{
Hermawan $^{1^{*}}$, Ridzqi Hartanto ${ }^{2}$ \\ ${ }^{1}$ Fakultas Ilmu Olahraga, Universitas Negeri Jakarta. Jl. Pemuda no. 10 Rawamangun Jakarta Timur \\ *Corresponding Author Email: hernawan.fikunj@gmail.com
}

\begin{abstract}
Abstrak : Tujuan penelitian ini yaitu untuk mengetahui pengaruh dari variabel- variabel bebas yaitu metode latihan dan power otot tungkai terhadap variabel terikat yaitu peningkatan kemampuan jump service. Metode penelitian yang digunakan adalah desain penelitian treatment by level $2 \times 2$. Penelitian dilaksanakan di club Tunas Rafflesia Bengkulu. Data diperoleh dari tes kemampua jump service, sedangakan analisis data dilakukan dengan teknik statistik analisis varian. Hasil penelitian menyimpulkan hal-hal berikut: (1) terdapat perbedaan kemampuan jump service yang signifikan antara kelompok yang diberikan metode latihan barrier hops dan kelompok yang diberikan metode latihan box jump, (2) terdapat interaksi antara metode latihan dan power otot tungkai terhadap kemampuan jump service pada anggota club Tunas Raflesia Kota Bengkulu, (3) terdapat perbedaan yang signifikan hasil kemampuan jump service antara metode latihan barrier hops dengan metode latihan box jump pada siswa yang memiliki power otot tungkai tinggi, (4) terdapat perbedaan yang signifikan hasil kemampuan jump service antara metode latihan barrier hops dengan metode latihan box jump pada siswa yang memiliki power otot tungkai rendah.
\end{abstract}

\section{Kata Kunci: Barrier Hops, Box Jumps, Power Otot Tungkai, Jump Service}

\begin{abstract}
The aim of this research was to know the effect of dependent variables that were practice method and the power of the muscle of the limbs toward independent variable that was jump service abiliy. The researcher used a treatment by level $2 \times 2$ as research design. The research was done in Tunas Rafflesia Kota Bengkulu club. The data was collected by jump service ability test, meanwhile the analysis technique was done by varians analysis statistic. The research result concluded the terms as follow: (1) there was any significant difference of the jump service ability between the group who was employed barrier hops method and the group who was empoyed box jump method, (2) there was an interaction between thepractice method and the power of the muscle of the limbs toward the jump sevice ability of the members of Tunas Rafflesia Kota Bengkulu club, (3) there was any significant difference of the jump service ability between the group of barrier hops method and the group of box jump method who had high power of the muscle of the limbs,(4) there was significant difference of the jump service ability between the group of barrier hops method and the group of box jump method who had low power of the muscle of the limbs.
\end{abstract}

Keyword: Barrier Hops, Box Jumps, The Power of the Muscle of the Limbs, Jump Service. 


\section{PENDAHULUAN}

Teknik dasar pertama yang dikenal dalam permainan bola voli adalah teknik melakukan servis., teknik servis pada bola voli secara sederhana adalah pemain berdiri di belakang garis belakang lapangan, melemparkan bola ke udara, kemudian memukul bola tersebut ke arah lapangan atau area lawan. Meskipun terdengar sederhana, namun pada pelaksanaan teknik ini juga ada beberapa hal yang harus menjadi perhatian. Teknik servis dalam permainan bola voli telah berkembang menjadi beberapa jenis, seperti servis bawah, servis atas, servis mengapung (float), servis lompat (jump servis) dan lain sebagainya.

Salah satu teknik servis yang dapt menghasilkan pukulan servis yang menukik dengan tajam dan keras sehingga dapat menimbulkan kesulitan bagi tim lawan penerima servis yaitu jump service. Dalam melakukan jump service, posisi awalan bervariasi tergantung pada pemain,awalan jump service pada umumnya dilakukan sekitar 3 meter. Awalan ini berguna sekali untuk memperoleh posisi awal yang mantap untuk melakukan lompatan sehingga memperoleh daya dorong lompatan yang tinggi, dengan pengaturan waktu yang tepat berguna untuk memukul bola dengan keras. Jump service adalah teknik servis yang dilakukan dengan melompat seperti teknik gerakan smash. Hasil pukulan ini akan menghasilkan pukulan top spin. Jump service merupakan teknik servis baru yang perlu dilatihkan dan dapat digunakan untuk memulai serangan dalam permainan bolavoli.

Namun dalam praktiknya tidak semua pemain mampu melakukan gerakan jump service dengan maksimal, ditemukan adanya masalah dalam penguasaan teknik jump service. Salah satunya yaitu jump service merupakan teknik yang sulit untuk dikuasai. Melakukan awalan dan lompatan yang selalu menjadi kesulitan dasar dalam melakukan gerakan jump service. Gerakannya hampir sama seperti gerakan smash, akan tetapi penempatan yg jauh dari net menambah kesulitan lebih dbandingkan melakukan gerakan smash. Kurangnya gerakan eksplosif dari para pemain saat melakukan jump service, hal itu dikarenakan masih kurangnya media latihan eksplosif saat latihan bola voli. Masih belum tepatnya pengaturan timing saat melompat dan memukul bola oleh para pemain, karena pengaturan timing sangat diperlukan saat memukul bola untuk hasil service yang maksimal.Powersebagai salah satu kondisi 
fisikpara peserta didik saat melakukan jump service juga merupakan faktor penting untuk mendapatkan hasil servis yang maksimal., Diperlukan metode latihan yang tepat guna meningkatkan keterampilan jump service para pemain bola voliuntuk mengatasi masalah tersebut. Teknik jump service membutuhkan pergerakan yang eksplosif, maka untuk menciptakan gerakan yang eksplosif itu dbutuhkan latihan yg cocok seperti latihan barrier hop dan box jump yang merupakan bagian dari latihan plyometric. Plyometric adalah latihan atau ulangan yang bertujuan menghubungkan gerakan kecepatan untuk menghasilkan gerakan-gerakan eksplosif. Menurut Chu dan Myer (2013) plyometric mempunyai keuntungan, memanfaatkan gaya dan kecepatan yang dicapai dengan percepatan berat badan melawan grafitasi, hal ini menyebabkan gaya kecepatan dalam latihan plyometric merangsang berbagai aktivitas olahraga seperti melompat, berlari dan melempar lebih sering dibandingkan dengan latihan beban atau dapat dikatakan lebih dinamis atau eksploisive. Oleh karena itu, latihan plyometric sangat cocok pada cabang olahraga yang membutuhkan kemampuan daya ledak otot tungkai untuk meningkatkan tinggi lompatan seperti pada permainan bolavoli yang banyak melakukan gerakan lompatan seperti pada saat melakukan blocking, smash, maupun jumpserve.

Latihan plyometric ini banyak digunakan karena metode latihannya yang efektif dan banyak sekali bentuk modifikasi yang biasa digunakan maupun diciptakan oleh seorang pelatih. Barrier hop dan box jump merupakan latihan yg cocok menurut peneliti untuk teknik yg menciptakan gerakan ekplosif pada jump service. Box jump adalah sebuah latihan yang memakai beberapa kotak dengan metode latihan dilakukan dengan berbagai gerakan dimana ukuran dan tinggi kotak dapat disesuaikan. Menurut chu (2013) latihan Barrier Hops adalah latihan yang dilakukan pada gawang-gawang atau rintangan-rintangan yang tingginya (antara $30-90 \mathrm{~cm}$ ) diletakkan disuatu garis dengan jarak yang ditentukan dengan kemampuan,

Oleh karena teknik jump service dan latihan plyometric merupakan kegiatan dengan gerakan yang eksplosif khususnya pada otot tungkai. Power otot tungkai pemain menjadi salah satu faktor pendukung dalam melakukan jump service maupun latihan plyometric. Widiastuti (2015) mendefinisikan bahwa: "power atau sering pula disebut dengan daya eksplosif adalah suatu kemampuan gerak yang sangat penting untuk menunjang aktivitas pada setiap cabang olahraga". Hasil gerak 
olahraga yang baik dapat ditentukan jika seseorang memiliki daya eksplosif yang baik pula, seperti hasil tendangan yang keras, kecepatan berlari, lompatandan gerakan olahraga lain sebagainya. Dengan demikian power atau daya ledak ini sangat berperan penting dan bepengaruh pada hasil kemampuan seorang atlet dalam melakukan berbagai gerakan olahraga yang baik. Namun karena masih terbatasnya hasil penelitian yang menyatakan bahwa tingkat power otot tungkai berbanding lurus dengan hasil jump service, maka penelitian tentang pengaruh power otot tungkai terhadap hasil keterampilan jump service menjadi penting untuk dilakukan guna mendapatkan hasil yang optimal.

Secara umum, tujuan penelitian ini adalah untuk mengkaji dan mencari informasi mengenai pengaruh metode latihan dan power otot tungkai terhadap kemampuan jump service pada permainan bola voli. Sedangkan, secara khusus tujuan penelitian ini yaitu untuk memperoleh data empirik tentang: (1) perbedaan hasil keterampilan jump service bola voli menggunakan metode latihan barrier hop dan metode latihan box jump , (2) pengaruh interaksi antara metode latihan dan power otot tungkai terhadap keterampilan jump service bola voli, (3) perbedaan hasil keterampilan jump service bola voli antara metode latihan barrier hop dengan tingkat power otot tinggi dan metode latihan box jump dengan tingkat power otot tungkai tinggi. (4) perbedaan hasil keterampilan jump service bola voli antara metode latihan barrier hop dengan tingkat power otot tungkai rendah dan metode latihan box jump dengan tingkat power otot tungkai rendah.

\section{METODE}

Penelitian ini dilaksanakan di Club Tunas Raflesia Kota Bengkulu yang bertempat di Jl. Sawah Lebar Kota Bengkulu Provinsi Bengkulu. Penelitian ini dilaksanakan pada bulan 8 Maret-28 April sesuai jadwal latihan anggota club Tunas Raflesia Kota Bengkulu yaitu sebanyak dua kali pertemuan dalam seminggu. Dengan demikian jumlah latihan atau perlakuan sebanyak 16 kali pertemuan Penelitian ini dilakuka dengan menggunakan metode eksperimen. Fraenkel, Wallen, (2006) mengemukakan metode eksperimen sering digunakan karena dianggap sebagai metode yang paling kuat yang ada untuk mempelajari hubungan sebab akibat.Adapun rancangan penelitiannya adalah desain Treatment by Level $2 x$ 2. Bentuk dari rancangan penelitian seperti yang terlihat dalam Tabel 1.

Populasi terjangkau adalah anggota club Tunas Rafflesia Kota Bengkulu. Data 
berupa hasil tes kemampuan jump service, sedang analisis data dilakukan dengan menggunakan teknik analisis varians (Gall dkk, 2003:405). Berdasarkan hasil analisis varians menunjukkan adanya pengaruh utama antara variabel bebas terhadap variabel terikat, dan terdapat interaksi antara variabel bebas hubungannya dengan variabel terikat, maka analisis dilanjutkan dengan uji Tukey atau Tukkey's HSD (honestly significant difference) test(Kirk, 1982). Sebagai syarat pengujian terlebih dahulu melakukan uji normalitas dengan Liliefors dan uji homogenitas dengan Barlett.

Tabel 1. Desain treatment by level $2 \times 2$

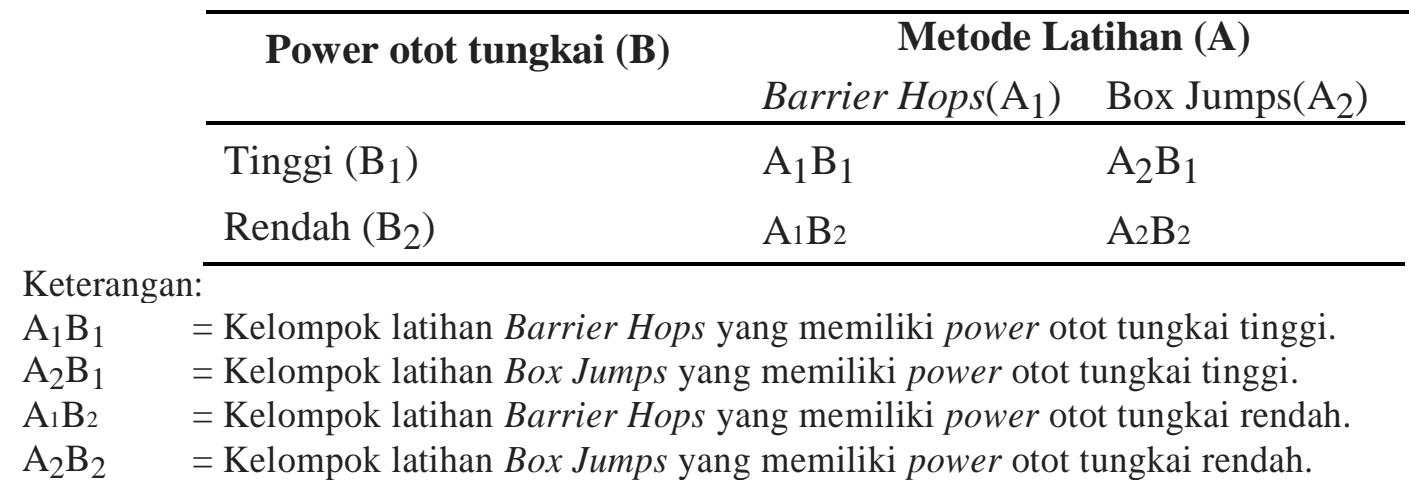

\section{HASIL DAN PEMBAHASAN}

Deskripsi data Berdasarkan hasil penelitian diperoleh data pada setiap kelompok latihan kemampuan jump service dapat dilihat pada tabel 2 berikut.

Tabel 2. Deskripsi Data

\begin{tabular}{crrrrrr}
\hline Data & N & Range & Minimum & Maximum & Mean & $\begin{array}{c}\text { Std. } \\
\text { Deviation }\end{array}$ \\
\hline A1 & 30.00 & 40.00 & 70.00 & 53.7500 & 10.87186 & 30.00 \\
A2 & 24.00 & 41.00 & 65.00 & 51.5500 & 6.02167 & 24.00 \\
A1B1 & 13.00 & 57.00 & 70.00 & 63.9000 & 3.69534 & 13.00 \\
A1B2 & 8.00 & 40.00 & 48.00 & 43.6000 & 2.63312 & 8.00 \\
A2B1 & 21.00 & 44.00 & 65.00 & 53.9000 & 6.74043 & 21.00 \\
A2B2 & 14.00 & 41.00 & 55.00 & 49.2000 & 4.34102 & 14.00 \\
Valid N & 10 & & & & & \\
(listwise) & & & & & & \\
\hline
\end{tabular}

Uji Normalitas
Uji normalitas pada penelitian ini dilakukan pada setiap kelompok kemampuan jump service, baik kelompok 
yang diberikan metode latihan barrier hops dan box jump, maupun kelompok yang memiliki power otot tungkai tinggi dan rendah. Hasil analisis uji normalitas data menggunakan uji Liliefors pada taraf signifkansi $\alpha=0,05$ untuk masing-masing kelompok sampel kemampuan jump service disajkan dalam tabel 3 .

Tabel 3. Rangkuman Hasil Uji Normalitas Data

\begin{tabular}{clccc}
\hline No & Kelompok Sampel & Sig. (2-tailed) & $\boldsymbol{\alpha}=\mathbf{0 , 0 5}$ & Kesimpulan \\
\hline 1 & Barrier Hops - Tinggi & 0,200 & 0,05 & Data berdistribusi normal \\
2 & Barrier Hops - Rendah & 0,200 & 0,05 & Data berdistribusi normal \\
3 & Box Jump - Tinggi & 0,149 & 0,05 & Data berdistribusi normal \\
4 & Box Jump - Rendah & 0,200 & 0,05 & Data berdistribusi normal
\end{tabular}

\section{Uji Homogenitas}

Pengujian homogenitas data pada penelitian ini menggunakan statistika uji Barlett. Uji homogenitas ini dilakukan terhadap empat kelompok eksperimen yang terdiri dari dua metode latihan yaitu barrier hops yang memiliki power otot tungkai tinggi (A1B1), barrier hops yang memiliki power otot tungkai rendah (A1B2), box jump yang memiiki power otot tungkai tinggi (A2B1), dan box jump yang memilki power otot tungkai rendah (A2B2). Hasil analisis homogenitas keempat kelompok data sampel hasil kemampuan jump service diperoleh nilai $\mathrm{xh} 2=3,11$. Pada taraf signifikansi $\alpha=0,05$ dan derajat kebebasan $\mathrm{dk}=3$ diperoleh harga $x t 2=7,81$. Karena nilai $x h 2=3,11$ lebih kecil dari $x t 2=7,81$, maka dapat disimpulkan bahwa data dari keempat kelompok sampel penelitian memiliki varian yang sama atau homogen. Dengan terpenuhinya persyaratan kenormalan distribusi data dan kehomogenitasan varian antara masing-masing kelompok data, pengujian hipotesis penelitian dilanjutkan dengan analisis Anova dua jalur.

Perbedaan Kemampuan Jump Service Metode Latihan Barrier Hops dan Box Jump

Pengujian hipotesis dalam penelitian ini dilakukan dengan menggunakan analisis varian (ANAVA) dua jalur dan dilanjutkan dengan uji Tuckey, jika terdapat interaksi di dalam pengujian. Analisis varian dua jalur digunakan untuk menguji pengaruh utama (main effect) dan interaksi (interaction effect) antara metode latihan dan power otot tungkai terhadap kemampuan jump service. Dengan menggunakan ANAVA dua jalur diperoleh hasil pengujian hipotesis sebagai berikut. 
Gladi Jurnal Ilmu Keolahragaan, 09 (2), Oktober - 114

Hernawan, Ridzqi Hartanto

Hasil uji hipotesis pertama dapat dilihat dalam tabel 4 berikut

Tabel 4. Rangkuman Hasil Uji ANOVA Dua Jalur

\begin{tabular}{lrrrrr}
\hline \multicolumn{1}{c}{ Source } & $\begin{array}{c}\text { Type III Sum } \\
\text { of Squares }\end{array}$ & df & Mean Square & \multicolumn{1}{c}{ F } & Sig. \\
\hline Corrected Model & $2219.300^{\mathrm{a}}$ & 3 & 739.767 & 34.867 & .000 \\
Intercept & 110880.900 & 1 & 110880.900 & $5.226 \mathrm{E} 3$ & .000 \\
Metode & 48.400 & 1 & 48.400 & 2.281 & .010 \\
Power & 1562.500 & 1 & 1562.500 & 73.645 & .000 \\
Metode * Power & 608.400 & 1 & 608.400 & 28.676 & .000 \\
Error & 763.800 & 36 & 21.217 & & \\
Total & 113864.000 & 40 & & & \\
Corrected Total & 2983.100 & 39 & & & \\
\hline
\end{tabular}

Berdasarkan tabel di atas, dapat disimpulkan bahwa terdapat perbedaan kemampuan jump service antara kelompok yang diberikan metode latihan barrier hops dan kelompok yang diberikan metode latihan box jump. Hal ini terlihat dari pvalue variabel metode $=0,010<0,05$ yang menyatakan bahwa H0 ditolak. Selanjutnya untuk p-value variabel power $=0,00>0,05$ yang menyatakan bahwa $\mathrm{H} 1$ diterima yaitu terdapat perbedaan rata-rata kemampuan hasil jump service antara kelompok yang memiliki power otot tungkai yang tinggi dan kelompok yang memiliki power otot tungkai yang rendah. Selain itu tabel di bawah ini juga menunjukkan bahwa terdapat perbedaan yang signifikan pada metode dan power otot tungkai.

Berdasarkan hasil pengolahan dan analisis data penelitian, diperoleh hasil bahwa hipotesis yang menyatakan bahwa metode latihan barrier hops lebih tinggi pengaruhnya daripada metode latihan box jump terhadap hasil kemampuan jump service diterima. Ini berarti bahwa metode latihan barrier hops memberikan pengaruh lebih baik dibandingkan dengan metode latihan box jump dalam menguasai teknik jump service pada permainan bola voli.

Menurut Chu dan Gregory (2013), latihan BarrierHops adalah latihan yang dilakukan pada gawang-gawang atau rintangan-rintangan yang tingginya (antara 30-90 cm) diletakkan di suatu garis dengan jarak yang ditentukan dengan kemampuan. Rintangan akan jatuh bila atlet membuat kesalahan, start dimulai dengan berdiri di belakang rintangan, gerakan meloncat yang melewati rintangan-rintangan dengan kedua kaki bersaman. Gerakan dimulai dari pinggang dan lutut merenggang. Gunakan ayunan kedua lengan untuk menjaga keseimbangan dan mencapai ketinggian. Barierhops merupakan salah satu bentuk latihan melompati rintangan yang disusun 
bederet kedepan maupun menyamping. Menurut Sandler (2015), barrier hops didefinisikan bahwa :"hurdle jumps are performed by jumping for height over hurdles from a single or double leg take off.". lompatan pada barrier hops bertujuan untuk mencapai ketinggian yang lebih dari rintangan yang diberikan baik menggunakan satu kaki ataupun dua kaki sekaligus.

Keunggulan dari metode latihan barrier hops ini dibandingkan dengan metode latihan box jump yaitu metode latihan barrier hops menekankan pada loncatan untuk mencapai ketinggian maksimum ke arah vertikal dan kecepatan gerakan kaki, sehingga sangat memungkinkan jika penerapan metode latihan barrier hops mampu berpengaruh lebih bai dalam meningkatkan kemampuan hasil jump service (Sajoto,2002). Selain itu, untuk melakukan lompatan pada jump service dibutuhkan kecepatan dan ketepatan dalam melakukan service pada bola voli, oleh karena itu barrier hops melatih kekuatan dan kecepatan otot tungkai untuk memberikan daya dorong saat melakukan lompatan.

Interaksi Metode Latihan dan Power Otot Tungkai terhadap Kemampuan Jump Service

Berdasarkan tabel 4 diperoleh pvalue untuk metodedan power = $0,000<0,05$, yang berarti bahwa $\mathrm{H} 0$ ditolak yaitu terdapat pengaruh interaksi yang signifikan antara faktor metode latihan dan faktor power otot tungkai terhadap hasil kemampuan jump service.

Hasil dari pengujian hipotesis kedua diketahui bahwa terdapat interaksi antara metode latihan dan power otot tungkai terhadap kemampuan jump service. Interaksi keduanya terlihat pada adanya perbedaan pengaruh perlakuan terhadap kemampuan jump service pada kedua tingkat power otot tungkai. Permasalahan ini menunjukkan bahwa dalam menentukan penggunaan metode latihan barrier hops dan box jump hendaknya terlebih dahulu dapat memperhatikan power otot tungkai siswa. Pada siswa yang memiliki power otot tungkai tinggi, metode latihan barrier hops akan lebih efektif apabila digunakan. Sedangkan untuk siswa dengan power otot tungkai rendah akan lebih efektif apabila digunakan metode latihan box jump.

Secara keseluruhan temuan dari hasil penelitian ini menunjukkan bahwa baik power otot tungkai maupun metode latihan plyometrix keduanya merupakan variabel penting dalam upaya meningkatkan hasil kemampuan jump service khususnya terhadap anggota club Tunas Raflesia Kota Bengkulu. Kedua variabel tersebut satu sama lain saling mendukung dalam upaya mencapai hasil 
latihan bola voli yang optimal. Apabila power otot tungkai berfungsi sebagai faktor pertama yang membantu menambah kekuatan dan kecepatan siswa dalam melakukan lompatan dan pukulan yang tepat pada jump service, maka metode latihan plyometrix (barrier hops dan box jump) merupakan faktor kedua yang sangat potensial menyokong hasil kemampuan jump service yang sebaik-baiknya.

Perbedaan Kemampuan Jump service Metode Latihan Barrier Hops dan Metode Latihan Box Jump pada Siswa yang Memiliki Power Otot Tungkai Tinggi

Dari tabel berikut ini dapat disimpulkan bahwa terdapat perbedaan hasil kemampuan jump service antara kelompok yang menggunakan metode latihan barrier hops dan metode latihan Hasil penelitian menunjukkan adanya perbedaan yang signifikan hasil kemampuan jump service antara metode latihan barrier hops dengan metode latihan box jump pada siswa yang memiliki powerbox jump pada kelompok yang memiliki power otot tungkai tinggi. Pengujian simple effect untuk B1 (A1B1A2B1) mempunyai nilai signifikan 0,000< 0,05 sehingga H0 ditolak.

otot tungkai tinggi. Pada siswa yang memiliki power otot tungkai tinggi menggunakan metode latihan barrier hops memperoleh hasil kemampuan jump service lebih tinggi dibandingkan dengan yang menggunakan metode latihan box jump.

Power atau daya ledak eksplosif yang dhasilkan oleh otot tungkai merupakan komponen dan faktor yang penting dalam penunjangan gerakan aktifitas fisik yang bersifat eksplosif seperti gerakan lompat. Peranan power pada komponen kondisi fisik gerakan hampir ada pada setiap cabang olahraga. Bompa dan Carrera menjelaskan "power is the main ingredient for all the sports in which the rate of producing,and especially of displaying, force, speed, and agility is high" (Bompa dan Carera, 2005). Power atau daya ledak merupakan hasil dari bahan utama yang secara khusus dihasilkan oleh kekuatan, kecepatan dan kelincahan yang tinggi. Power didapat atau dhasilkan dari gabungan kekuatan dan kecepatan serta kelincahan yang tinggi yang dilakukan secara bersamaan. Teori ini mendukung hasil penelitian pada hipotesis ketiga ini yang menyatakan bahwa terdapat pengaruh yang signifikan terhadap hasil kemampuan jump service antara metode latihan barrier hops dengan metode latihan box jump pada siswa yang memiliki power otot tungkai tinggi. 


\section{Tabel 5. Rangkuman Hasil Uji Tukey}

\begin{tabular}{lllllll}
\hline \hline & & \multicolumn{2}{c}{ Mean } & & \multicolumn{3}{c}{$95 \%$ Confidence Interval } \\
(I) A & (J) A & Difference & (I-J) & Std. Error & \multicolumn{1}{c}{ Sig. } & \multicolumn{2}{c}{ Lower Bound Upper Bound } \\
\hline A1B1 & A1B2 & $20.30000^{*}$ & 2.05994 & .000 & 14.7521 & 25.8479 \\
& A2B1 & $10.00000^{*}$ & 2.05994 & .000 & 4.4521 & 15.5479 \\
& A2B2 & $14.70000^{*}$ & 2.05994 & .000 & 9.1521 & 20.2479 \\
A1B2 & A1B1 & $-20.30000^{*}$ & 2.05994 & .000 & -25.8479 & -14.7521 \\
& A2B1 & $-10.30000^{*}$ & 2.05994 & .000 & -15.8479 & -4.7521 \\
& A2B2 & $-5.60000^{*}$ & 2.05994 & .037 & -11.1479 & -.0521 \\
A2B1 & A1B1 & $-10.00000^{*}$ & 2.05994 & .000 & -15.5479 & -4.4521 \\
& A1B2 & $10.30000^{*}$ & 2.05994 & .000 & 4.7521 & 15.8479 \\
& A2B2 & 4.70000 & 2.05994 & .121 & -.8479 & 10.2479 \\
A2B2 & A1B1 & $-14.70000^{*}$ & 2.05994 & .000 & -20.2479 & -9.1521 \\
& A1B2 & $5.6000 *^{*}$ & 2.05994 & .037 & .0521 & 11.1479 \\
& A2B1 & -4.70000 & 2.05994 & .121 & -10.2479 & .8479 \\
\hline
\end{tabular}

Perbedaan Kemampuan Jump service Metode Latihan Barrier Hops dan Metode Latihan Box Jump pada Siswayang Memiliki Power Otot Tungkai Rendah

Dari hasil pengujian hipotesis keempat (lihat tabel 5) menunjukkan bahwa terdapat perbedaan yang signifikan antara hasil kemampuan jump service siswa yang diberikan metode latihan barrier hops dan metode latihan box jump pada kelompok siswa yang memiliki power otot tungkai rendah. Hal ini dapat dilihat dari hasil uji Tukey untuk B2 (A1B2-A2B2) dengan signifikan $0,037<0,05$ yang artinya bahwa H0 ditolak.

Hasil uji hipotesis keempat ini menunjukkan bahwa terdapat perbedaan antara kelompok siswa yang diberikan metode latihan barrier hops dan metode latihan box jump yang memiliki power otot tungkai rendah. Kemampuan jump service antara metode latihan barrier hop dan box jump berdasarkan hasil penelitian menunjukkan bahwa ada perbedaan hasil pemain dengan power otot tungkai kategori rendah. Peserta didik yang memiliki power otot tungkai kategori rendah diduga tidak berpengaruh besar terhadap peningkatan kemampuan jump service.

Power otot tungkai pemain yang rendah akan berpengaruh terhadap kemampuan jump service. Hal ini dikarenakan power otot tungkai juga merupakan salah satu faktor yang mempengaruhi metode latihan. Latihan box jump dan barrier hop merupakan 
latihan dengan tujuan peningkatan gerakan eksplosif, jadi dengan gerakan dasar power otot yang rendah mempengaruhi peningkatan latihan maupun gerakan kemampuan pada jump service.

Berdasarkan hasil penelitian, dapat disimpulkan bahwa kelompok yang diberikan metode latihan box jump dengan power otot tungkai rendah dapat menghasilkan kemampuan jump service yang lebih baik dibandingkan kelompok yang diberikan metode latihan barrier hops dengan power otot tungkai rendah. latihan barrier hops dengan metode latihan box jump pada siswa yang memiliki power otot tungkai tinggi pada anggota club Tunas Raflesia Kota Bengkulu, dan (4) terdapat perbedaan yang signifikan hasil kemampuan jump service antara metode latihan barrier hops dengan metode latihan box jump pada siswa yang memiliki power otot tungkai rendah pada anggota club Tunas Raflesia Kota Bengkulu.

\section{KESIMPULAN}

Bertolak dari hasil pengujian hipotesis penelitian dan analisis data yang dilakukan dapat disimpulkan beberapa ha seperti berikut: (1) terdapat perbedaan kemampuan jump service yang signifikan antara kelompok yang diberikan metode latihan barrier hops dan kelompok yang diberikan metode latihan box jump dalam permainan bola voli pada anggota club Tunas Raflesia Kota Bengkulu, (2) terdapat interaksi antara metode latihan dan power otot tungkai terhadap kemampuan jump service pada anggota club Tunas Raflesia Kota Bengkulu, (3) terdapat perbedaan yang signifikan hasil kemampuan jump service antara metode.

\section{DAFTAR PUSTAKA}

Akhmadi,Nuril. (2007). Panduan Olahraga BolaVoli.Solo: Era Pustaka Utama

Bompa,Tudor \& Carrera. (2005) Periodization Training For Sports. Champaign: Human Kinetics

Chu Donald. A. dan Gregory. D. Myer. (2013) Plyometrics. Champaign: Human Kinetics

Sandler, D. (2015) Sports Power. Champaign : Human Kinetic

Sugiyono. 2011. Metode Penelitian Pendidikan. Bandung: Alfabeta

Tangkudung, James.2012. Kepelatihan Olahraga. Jakarta: cerdas Jaya

Tangkudung, James. 2015. MacamMacam Metodologi Penelitian. Jakarta: Lensa Media Pustaka Indonesia.

Widiastuti.2015. Tes dan Pengukuran Olahraga. Jakarta: Rajawali Pers 